\title{
ACTIVITIES OF UNITED TERRITORIAL COMMUNITIES AS A BODY OF LOCAL GOVERNMENT IN THE CONDITIONS OF POWER DECENTRALIZATION IN UKRAINE
}

\author{
Lyudmila Pronko', Tatyana Kolesnik' ${ }^{2}$ Oksana Samborska ${ }^{3}$ \\ Vinnytsia National Agrarian University, Ukraine
}

\begin{abstract}
The purpose of the article is to study the system of united territorial communities (UTC) formation and to conduct the analysis of their activities effectiveness, in the conditions of decentralization of power. Methodology. The methodological basis for the study of decentralization and local government reforms, the strengthening of the political status of the local government body, and the decentralization of power are the Constitution of Ukraine, Laws of Ukraine, Presidential Decrees, as well as publications on these issues by domestic and foreign authors. Results. It was established that, in accordance with Article 140 of the Constitution of Ukraine, local government has the right of the territorial community to resolve issues of local importance independently. The Decree of the President of Ukraine "On Priority Measures for the Development of Local Government in Ukraine for 2017" identified the development of local government as one of the priority directions of the state's development. In April 2017, the Government adopted the Order "On Approval of the Medium-Term Plan for Priority Actions of the Government by 2020 and the Government Priority Action Plan for 2017", which provides for the 100\% consolidation of local councils at the baseline level in capable territorial communities by 2020. As a result, according to the Law of Ukraine "On Voluntary Association of Territorial Communities", the voluntary association of territorial communities of villages, settlements, cities is carried out while subjected to ensuring the quality and availability of public services. State programs for supporting the development of the territorial community and building the infrastructure of the village (towns, cities) have been developed. Practical implication. Proposal reform on voluntary association of communities enables them to acquire the status of the capable local community, in which local sources of budget revenues, infrastructure, and human resources are sufficient to meet the interests of residents. The territorial community independently manages the property that is in communal ownership; establishes local taxes and fees in accordance with the law; ensures the holding of local referendums and the realization of their results; establish, reorganize, and liquidate communal enterprises, organizations, and institutions, and also controls their activities; decides other issues of local importance, assigned by law to their competence. Value/originality. In carrying out any reforms, in terms of priority, systematic state intervention should be provided by legislative regulation and dissolution of the district councils in areas where all communities are united in UTC.
\end{abstract}

Key words: united local communities, local authorities, local government, decentralization, public authorities' reform, local community, public control of local governments.

JEL Classification: R1, R5, P2, P25, D1

\section{Introduction}

The European Charter of Local Government was adopted under the auspices of the Congress of Local and Regional Authorities of Europe and came into force on September 1, 1988. The Charter defines the basic principles and mechanisms of governing bodies' activity by states - members of the Council of Europe.
The decentralization of power, the application of the principle of subsidiarity (solving specific problems at the closest to everyday needs of people at the level of power) is the main idea of the charter.

The Charter obliges the state to consolidate its domestic law and apply in practice a set of legal rules guaranteeing the political, administrative, and financial

\footnotetext{
Corresponding author:

${ }^{1}$ Department of Management and Law, Vinnytsia National Agrarian University.

E-mail: pronkoL@ukr.net

${ }^{2}$ Department of Management and Law, Vinnytsia National Agrarian University.

E-mail: sergej.kolesnik@gmail.com

${ }^{3}$ Department of Management and Law, Vinnytsia National Agrarian University.

E-mail: super_oksana30@ukr.net
} 
independence of municipal entities. It also establishes the need for constitutional regulation of the autonomy of local government.

Ukraine ratified the charter on July 15, 1997. The Constitution of Ukraine of 1996 consolidated the basic legal principles of functioning of the mechanism of power organization, fixed in the charter. In 1997-99, the Verkhovna Rada of Ukraine adopted the Law on Local State Administrations, the Law on the Status of the Capital of Ukraine in Kyiv, and the Constitution of the Autonomous Republic of Crimea. On May 28, 1998, Congress of Local and Regional Authorities of the Council of Europe adopted Recommendations on Local and Regional Democracy in Ukraine (Groisman, 2017).

According to the Article 5 of the Constitution of Ukraine, the bearer of sovereignty and the only source of power in Ukraine are the people. The people exercise power directly and through state authorities and local government bodies. The right to define and change the constitutional system in Ukraine belongs exclusively to the people and cannot be usurped by the state, its organs or officials. According to the Article 140 of the Constitution of Ukraine, local government - is the right of the territorial community to independently resolve issues of local importance within the framework of the Constitution and Laws of Ukraine (Laws of Ukraine, 1996).

Thus, local government is a real guaranteed ability of a territorial community to independently or under the responsibility of elected bodies and officials to resolve matters of local importance within the limits defined by the Constitution and laws of Ukraine.

Today, the development of local government in conditions of decentralization of power, good governance, and decision-making is an important factor in the development of a territorial community and a democratic society. Therefore, the study of the decentralization power system, material and financial provision of the territorial community and their associations is a priority task nowadays.

\section{Reform of local government in decentralization conditions}

The reform of local government on a decentralized basis is one of the most effective reforms initiated by the government.

The decentralization of power in Ukraine is based on the introduction of European values on the development of local democracy, the empowerment of territorial communities, and the right to use resources, providing the population with high-quality administrative services, which will enable to form a modern system of local government, increase the level of economic and social development of the territory.

By the Decree of the President of Ukraine "On Priority Measures of Local Self-Government
Development in Ukraine for 2017" (Decree of the President, 2016), development of local government as one of the priority directions of the state's development was determined. As a result, the Cabinet of Ministers of Ukraine in September 2016 adopted a plan of measures to implement the Concept of Reforming Local Government and Territorial Organization of Power in Ukraine (Order of the Cabinet of Ministers of Ukraine, 2016).

The main measures of the reform are: development of conceptual principles of reform in the spheres of education, healthcare, social protection, improvement of regulatory and legislative support for reform, strengthening of the level of responsibility of local government bodies for the decisions made, conducting explanatory work, providing advisory services to territorial communities. In April 2017, the Government adopted the Order "On Approval of the Medium-Term Plan for Priority Actions of the Government by 2020 and the Government Priority Action Plan for 2017" (Cabinet of Ministers of Ukraine, 2017), which provides for the $100 \%$ consolidation of local councils at the baseline level in capable territorial communities by 2020 (Order of the Cabinet of Ministers of Ukraine, 2016).

The reform of decentralization has received a significant support from the Ukrainian public, especially in the regions that are leaders in creating capable united territorial communities.

According to the Law on Local Government, the territorial community - is inhabited by permanent residents within a village, a settlement, a city that is an autonomous administrative-territorial unit, or a voluntary association of residents of several villages having a single administrative centre (Laws of Ukraine, 2016). Its main features are: the common territory of existence, the presence of common interests of local importance, social interaction of community members in the process of ensuring these interests, psychological self-identification of each member with the community, common communal property, payment of utility taxes (Moroz, 2008).

All territorial communities of villages, settlements, districts of cities or cities of Ukraine have the status of legal entities - owners, which, with the participation of most residents, hold general meetings for the adoption of the charter, fixing administrative boundaries, and determining the reporting procedure for the organs of the community and local government bodies.

According to the Law of Ukraine "On Voluntary Association of Territorial Communities" (Laws of Ukraine, 2015), voluntary association of territorial communities of villages, settlements, cities is carried out while subjected to ensuring the quality and accessibility of public services provided in a united territorial community that cannot be lower than before the merger. That is, the association of communities should 
acquire the status of a capable territorial community, in which local sources of the budget, infrastructure, and human resources are sufficient to meet the interests of the community.

\section{Organization and activity of united territorial communities in Ukraine}

The immediate process of organization of territorial communities started in June 2015 (Fig. 1). By the end of 2015, 159 united communities were organized in Ukraine. During 2015-2017, the number of united territorial communities increased by 526 units and counted 685 . The dynamics of the last three years shows that in 2016, the number of united communities grew more than twice and reached 366 units, and in 2017, comparatively since 2016 the growth rate was equal to $87 \%$.

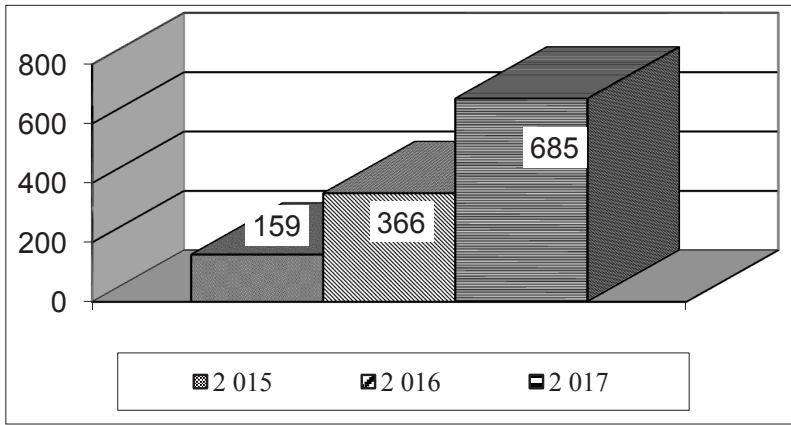

Fig. 1. The number of united territorial communities, units

This change contributed to the increase in the number of territorial communities that were included in the UTC (Figure 2).

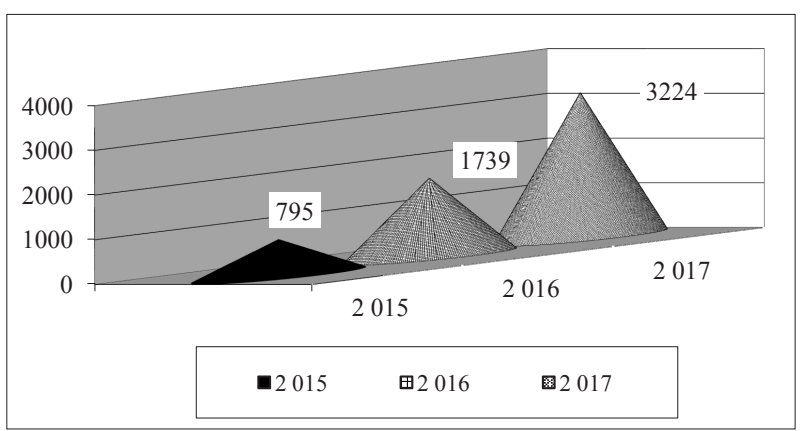

Fig. 2. The number of territorial communities that formed the united territorial communities

Consequently, according to Figure 2, we observe a progressive tendency to change the number of united territorial communities. In 2017, the number of such communities was 3224 units, which is 4 times over the value of 2015. Such a positive dynamics of change contributes to the increase in the number of inhabitants in the united territorial communities, the restoration and expansion of village infrastructure, etc. (Fig. 3).

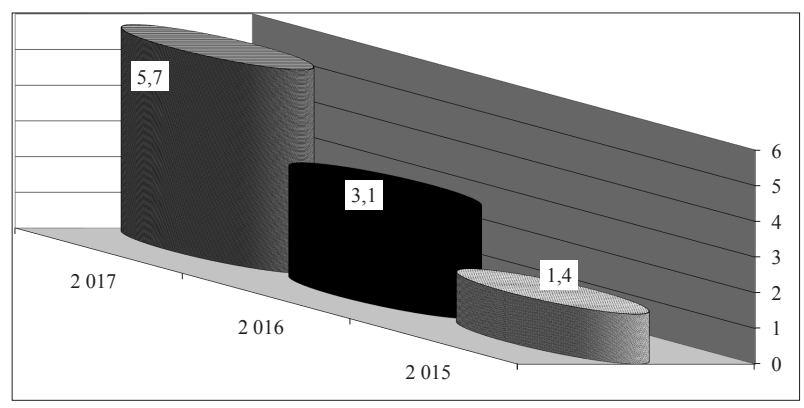

Fig. 3. The number of citizens in the united territorial communities, million people

During the period from 2015 to 2017, the number of residents with united communities grew by 4.3 million and counted 5.7 million. An increase in the size of the community should require local governments to introduce a number of programs for the development of the UTC infrastructure, environmental protection, and rational use of resources, which will increase the level of competition between communities.

In terms of the regions of our country, the largest number of united communities in Dnipro (56), Zhytomyr (45), Volyn (40), Ternopil (40), Poltava (39), and Vinnytsia (34) regions (Table 1).

The largest number of previously united communities is observed in Zhytomyr (328), Khmelnytskyi (320), Chernihiv (297), and Ternopil (240). We see quite a difficult situation regarding the organization of united territorial communities in Transcarpathian region (6), Luhansk (8), Donetsk (9), and Kyiv regions (9). In 2017, the largest number of UTC (more than 20) was organized in the Volyn, Dnipro, Poltava, Khmelnytskyi, and Zaporizhzhia regions.

Consequently, the process of decentralization of power and reform of local government bodies has positive results, but a considerable attention should be paid to the development of state programs to support the development of the territorial community and infrastructure development. Today, the level of state support has increased by 30 times (Fig. 4).

In 2017, the most priority areas of state support are: the subvention for social and economic development - almost $42 \%$ of all payments. About $33.5 \%$ is the proportion of subventions aimed at the development of medicine in rural areas, and 30\% are payments from the state fund for regional development.

The share of funds allocated by the EU in support of sectoral regional policy is $5.5 \%$.

Territorial communities are already creating their own executive committees and self-defence bodies in accordance with the Constitution of Ukraine, Article 143 of which states that territorial communities of villages, towns, cities, directly or through local governments that they have established, manage the property that is in communal ownership, establish local taxes and fees in accordance with the law; ensure the 
Vol. 4, No. 2, 2018

Table 1

The rating of regions in the formation of united territorial communities

\begin{tabular}{|c|c|c|c|c|c|c|c|}
\hline \multirow{3}{*}{ Region } & \multicolumn{4}{|c|}{ Number of united territorial communities } & \multirow{3}{*}{$\begin{array}{c}\text { Number of } \\
\text { united territorial } \\
\text { communities in } \\
\text { the region }\end{array}$} & \multirow{2}{*}{\multicolumn{2}{|c|}{$\begin{array}{c}\text { Territorial communities, which } \\
\text { were united } \\
\text { Total for } 2015-2017 \\
\end{array}$}} \\
\hline & \multirow{2}{*}{$\begin{array}{c}2015 \\
\text { Number of } \\
\text { UTC }\end{array}$} & \multirow{2}{*}{$\begin{array}{c}2016 \\
\text { Number of } \\
\text { UTC }\end{array}$} & \multirow{2}{*}{$\begin{array}{c}2017 \\
\text { Number of } \\
\text { UTC }\end{array}$} & \multirow[b]{2}{*}{ Total of UTC } & & & \\
\hline & & & & & & $\begin{array}{c}\text { TC, which were } \\
\text { united }\end{array}$ & $\%$ \\
\hline Vinnytsia & 2 & 19 & 13 & 34 & 707 & 101 & 14,3 \\
\hline Volyn & 5 & 10 & 25 & 40 & 412 & 169 & 41,0 \\
\hline Dnipropetrovsk & 15 & 19 & 22 & 56 & 348 & 165 & 47,4 \\
\hline Donetsk & 3 & 3 & 3 & 9 & 386 & 50 & 13,0 \\
\hline Zhytomyr & 9 & 23 & 13 & 45 & 631 & 328 & 52,0 \\
\hline Zakarpattia & 2 & 1 & 3 & 6 & 337 & 19 & 5,6 \\
\hline Zaporizhzhia & 6 & 10 & 20 & 36 & 299 & 133 & 44,5 \\
\hline Ivano-Frankivsk & 3 & 8 & 12 & 23 & 516 & 106 & 20,5 \\
\hline Kyiv & 1 & 1 & 7 & 9 & 659 & 49 & 7,4 \\
\hline Kropyvnytskyi & 2 & 3 & 8 & 13 & 415 & 37 & 8,9 \\
\hline Luhansk & 2 & 1 & 5 & 8 & 332 & 46 & 13,9 \\
\hline Lviv & 15 & 7 & 13 & 35 & 711 & 137 & 19,3 \\
\hline Mykolaiv & 1 & 19 & 9 & 28 & 313 & 103 & 32,9 \\
\hline Odesa & 8 & 3 & 14 & 25 & 490 & 108 & 22,0 \\
\hline Poltava & 12 & 6 & 21 & 39 & 503 & 145 & 28,8 \\
\hline Rivne & 5 & 13 & 7 & 25 & 365 & 93 & 25,5 \\
\hline Sumy & 1 & 13 & 14 & 28 & 419 & 131 & 31,3 \\
\hline Ternopil & 26 & 10 & 4 & 40 & 615 & 240 & 39,0 \\
\hline Kharkiv & 0 & 4 & 8 & 12 & 458 & 57 & 12,4 \\
\hline Kherson & 1 & 11 & 14 & 26 & 298 & 93 & 31,2 \\
\hline Khmelnytskyi & 22 & 4 & 13 & 39 & 605 & 320 & 52,9 \\
\hline Cherkasy & 3 & 3 & 20 & 26 & 556 & 97 & 17,4 \\
\hline Chernivtsi & 10 & 6 & 10 & 26 & 271 & 94 & 34,7 \\
\hline Chernihiv & 5 & 11 & 21 & 37 & 569 & 297 & 52,2 \\
\hline Total & 159 & 207 & 299 & 665 & 11215 & 3118 & 27,8 \\
\hline
\end{tabular}

holding of local referendums and the implementation of their results; form, reorganize and liquidate communal enterprises, organizations, and institutions, as well as control their activities; solve other issues of local importance, assigned by law to their competence (Laws of Ukraine, 1996).

For example, the work of territorial communities is carried out in the following areas:

- Conducting a joint communique with the community, building a cemetery fence.

- Prohibition of environmentally hazardous construction on its territory.

- Return rate, gardens owned by the community.

- Issue of the newsletter, initiation of the permanent reports of the rural chairman.

- Return the gardens on the territory of the abandoned military unit and the old palace in favour of the community.

- Recovery of the drainage system.

- Restoration of legality in the actions of the local militia.

- Stopping the illegal use of community land.

As a result of such measures, the local citizens can defend themselves from various manifestations of

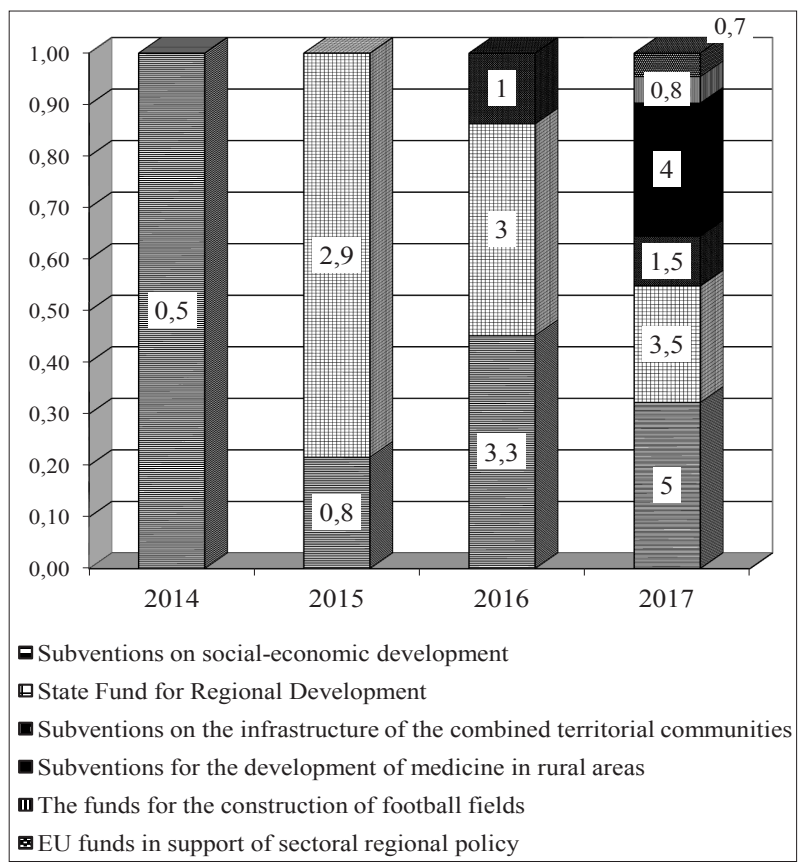

Fig. 4. Dynamics of state support for community development and infrastructure development

* the data is given in billion UAH 
corruption of local officials: illegal land privatization, deforestation, environmentally hazardous shale gas production, pollution of stakes, the arbitrariness of officials and police, forced association with other territorial communities, etc.

\section{State support and stimulation of the development of united territorial communities}

As it has been noted already, the reform of local government in our country is carried out with state support and stimulation, the main directions of which are:

1. Provision of subventions to local budgets of cooperation subjects in the priority areas of state policy;

2. Transfers of state-owned objects into communal ownership of objects of cooperation (unregulated);

3. Methodological, organizational, and other support.

Funds are distributed according to the formula, which takes into account the population and the total area of the united community. And the more rural population and territory in it, the greater the subvention will be (Fig. 5). The advantage is provided to the rural population to balance the disproportion in the development between the city and the countryside. After all, in villages, there are big problems with roads, with houses of culture, schools and kindergartens.

Infrastructure development includes road repairs, budget facilities, procurement and repair of vehicles and special equipment, construction of water pipes and much more. The total amount of the subvention is 1 billion hryvnia.

\section{The effectiveness of UTC activity in Vinnytsia region}

An additional allocation of funds from the state budget is made to increase the level of security of citizens through the implementation of the Program of security and law and order in the united territorial communities (Fig. 6). In the united territorial communities, citizens' security centres are created, which may include: a fire department, a police station, an ambulance. To create a centre, funds are allocated from the rural budget. In addition, the CPASs (the centre for providing administrative services) are created and work is carried out on the improvement of the level of comfort for the life of inhabitants of the territorial community. Here are some examples of disposals of local budgets in separate UTCs of the Vinnytsia region.

Zhdanivka United Territorial Community of Khmilnyk district opened the first citizen safety centre in Vinnytsia region. More than 2 million hryvnias were used to create a centre from the rural budget.

Yakushyntsi UTC has opened a new fire and rescue unit on the basis of a special-purpose emergency rescue unit of the State DPSU of Ukraine in Vinnytsia region, which will allow servicing 7 villages. The total cost of construction and repair works of the unit was about 700 thousand UAH, out of which 200 thousand UAH was allocated by Yakushyntsi UTC. The technique was purchased at the expense of regional and city budgets, with a total cost of almost 5 million hryvnias.

A municipal enterprise Yakushyntsi UTC "Municipal Police" was created. On the balance of Communist Party "Municipal Police," the rural council transferred the car
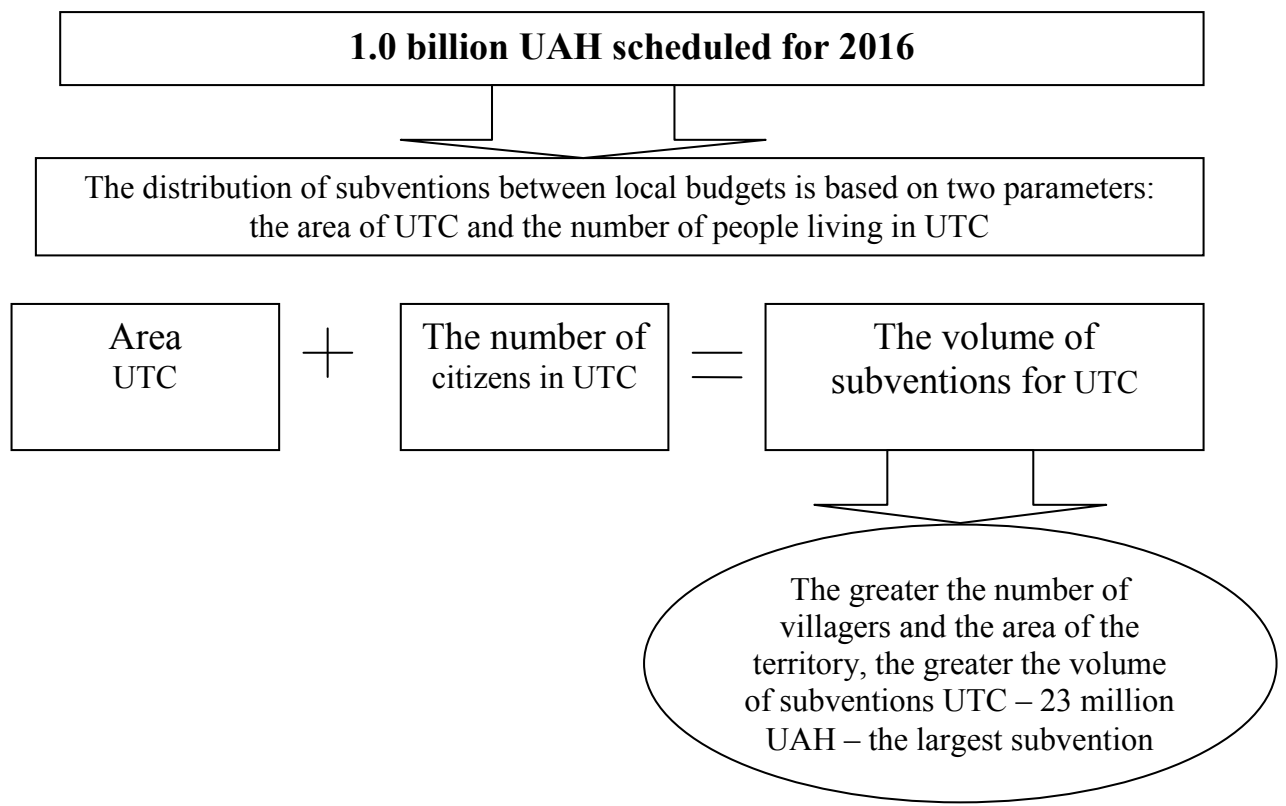

Fig. 5. Procedure for granting subventions from the state budget 


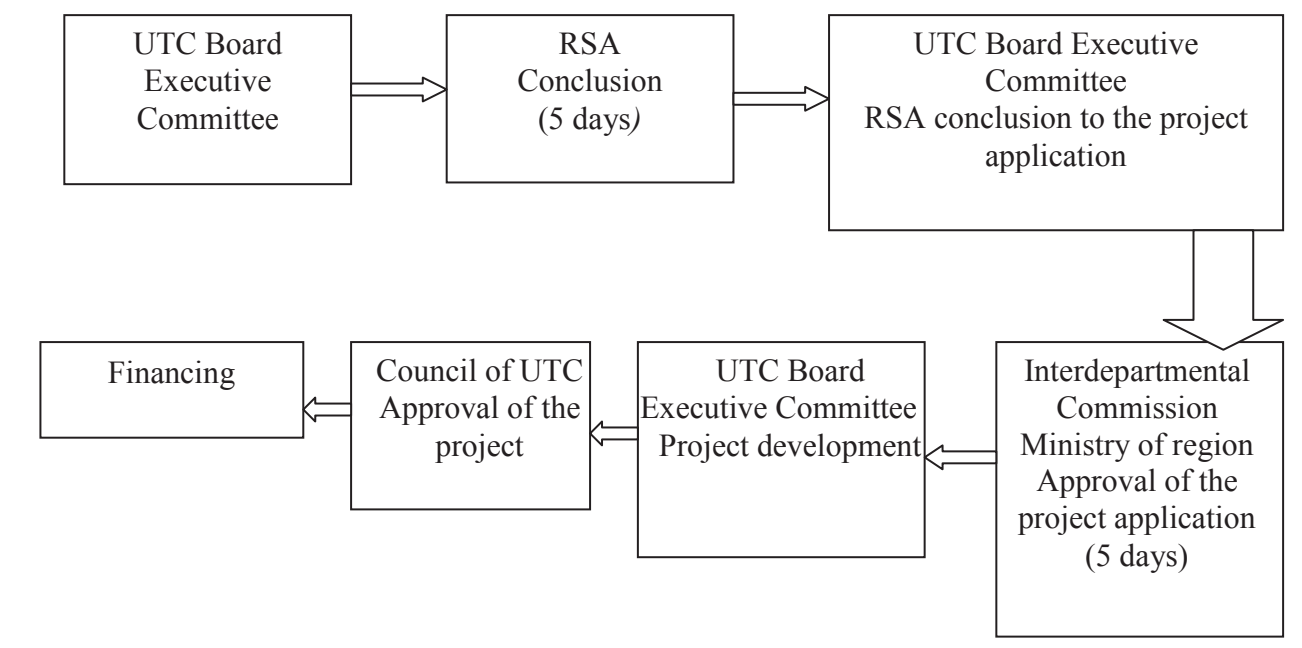

Effective use of financial support is possible only through well-established projects that should become the basis for the socio-economic development of united communities.

Fig. 6. Scheme of the procedure for using subventions of the state budget

"VAZ 2121 NIVA" for official use and prompt response to reports of residents of our settlements.

The project "Illintsi - a safe city" is aimed at creating comfortable conditions for the safe residence of residents and guests of Illintsi city and prevention of violations in the city by establishing specialized video surveillance. 12 video surveillance cameras purchased. Purchased a system of traffic light control. There are 2 transport and 2 pedestrian traffic lights installed on the pedestrian crossing in Illintsi on the Nezalezhnosti Street near the secondary school № 1 .

In Raihorod and Dashiv UTCs of Vinnitsa region, projects for the reconstruction of electric power lines for street lighting have been implemented at local budgets subventions for the formation of the infrastructure of the united territorial communities. The budget is 1.7 million UAH.

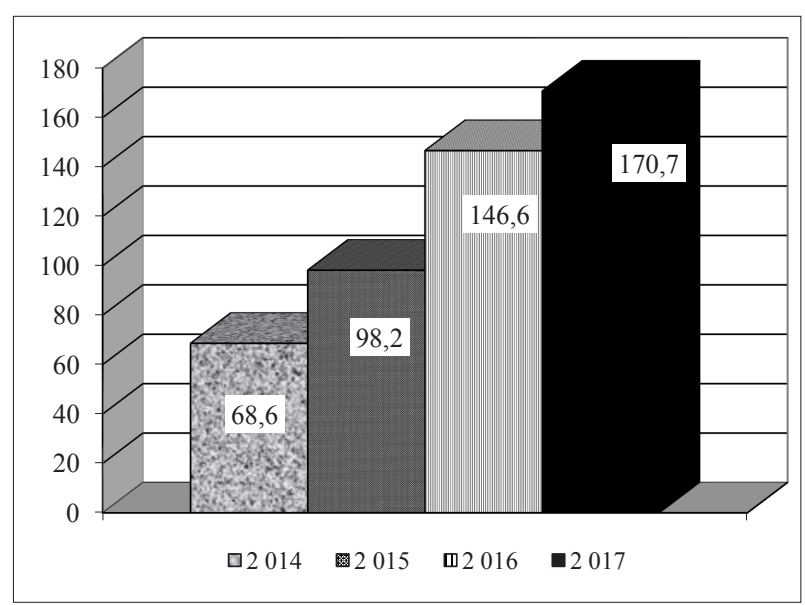

Fig. 7. The dynamics of changes in the size of local budgets' own revenues in Ukraine, UAH billions
During 2017, major repairs of roads (sidewalks) are carried out in almost all UTCs of the region at the expense of a subvention from the state budget to local budgets for the formation of infrastructure of the joint territorial communities, which is almost $60 \%$ (27.4 million UAH) of the total amount foreseen for the region (45.7 million UAH) for 2017.

Consequently, with the creation of united territorial communities, the share of state subsidies increases and local budgets increase their own revenues (Fig. 7). For the period from 2014 to 2017, the amount of own income increased 2.5 times and amounted to about 171 billion UAH.

As a result, we have an increase in the share of local budgets in the general budget of Ukraine to almost 50\% (Fig. 8).

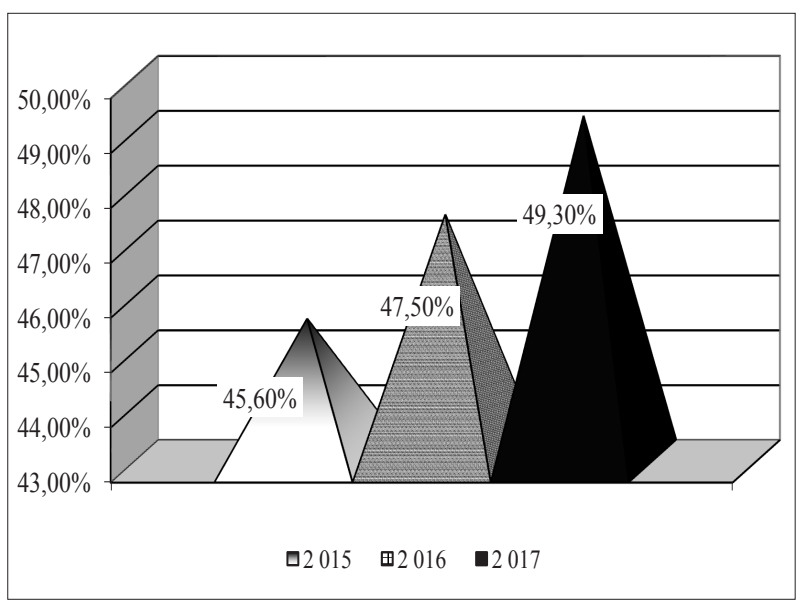

Fig. 8. The share of local budgets (with transfers) in the consolidated budget of Ukraine, \% 
But one should keep in mind that the state can stimulate cooperation with territorial communities if:

1. The capacity of subjects of cooperation to ensure the implementation of powers determined by the law is strengthened.

2. The cooperation involves additional resources, including financial ones.

3. More than three subjects of cooperation carry out UTC.

4. There is wide public participation in the implementation of UTC.

5. Implementation of investment programs and projects.

\section{The methodology of research}

The methodological basis for the study of local government reforms in the context of decentralization of power is the Constitution of Ukraine, the Laws of Ukraine, the Presidential Decrees, as well as publications on these issues of domestic and foreign authors. In this direction, domestic scientists have taken a number of important steps, including the study of theoretical foundations of the government, the constitutional principles of its implementation, the history of power in Ukraine, the features of modern national governments. The process of reforming local self-government in Ukraine was studied by many Ukrainian scientists in 2015, 2016, 2017.

\section{Findings}

With the creation of united territorial communities, the level of autonomy and financial independence increases, the share of state subsidies, which depends on the number of the territorial community, increases, and the size of own revenues of local budgets increases too. Provision of state support is possible due to a compliance with the legislative framework, wide public participation in the implementation of the UTC, and the implementation of investment programs and projects for the development of rural areas.

\section{Conclusions}

Consequently, the creation of UTC is a rather promising direction that ensures the development of local government in conditions of decentralization, which will enable communities, at their own discretion and in satisfaction of their own interests, to use property and income. But, along with the above-mentioned achievements and advantages in creating the united territorial communities, we certainly have a number of problems, the main ones of which, in our opinion, are:

- duplication of powers of the district state administration and executive bodies of the councils of UTC (provision of administrative, educational, medical services and even housing and communal services);

- ineffective use of local and state budget funds (expenditures for the maintenance of the apparatus of executive bodies of the UTC councils and the district administration in terms of implementation of duplication of powers);

- reducing the quality of service provision in individual villages in connection with the reduction of raion budget financing (in terms of educational, medical subventions);

- transfer of communal property from the district to the UTC, etc.

State interference will be solved by legislative regulation and early termination of powers of district councils in areas where all communities are united in the UTC.

\section{References:}

Cabinet of Ministers of Ukraine (2016) "Some issues of implementation of the Concept of Reforming Local SelfGovernment and Territorial Organization of Power in Ukraine: Order of the Cabinet of Ministers of Ukraine dated September 22, 2016 No. 688-p. Retrieved from: http://www.kmu.gov.ua/control/ru/cardnpd?docid

Cabinet of Ministers of Ukraine (2017) "On approval of the medium-term plan of the Government's priority actions by 2020 and the plan of priority actions for the year 2017: the order of the Cabinet of Ministers of Ukraine dated April 3, 2017, No. 275-p". Retrieved from: http:// www.kmu.gov.ua/control/uk/cardnpd?docid

Groisman V. (2017) Ukraynia-nini-blizka-do-vtilennya-khartiy-mistsevogo-samovryaduvannya. Retrived from: http//www.unn.com.ua/uk/news/15100373

Moroz O. (2008) Territorial community: the essence, formation and modern Ukrainian realities. Naukovyi visnyk, 2. The Verkhovna Rada of Ukraine (2014) "On Approving the Concept of Reforming Local Self-Government and Territorial Organization of Power in Ukraine: Order of the Cabinet of Ministers of Ukraine”. Retrieved from: http://zakon.rada.gov.ua/laws/show/

The Verkhovna Rada of Ukraine (2016) "On Priority Measures for the Development of Local Self-Government in Ukraine for 2017: Decree of the President of Ukraine dated 07.12.2016 № 545”. Retrieved from: http://zakon. rada.gov.ua/laws/show/

The Verkhovna Rada of Ukraine (2016) "The Law of Ukraine "On Local Self-Government in Ukraine" No. 280/97BP, adopted on May 21, 1997, in the wording of September 22, 2016, which took into account 112 amendments introduced in 1998-2016 by the Laws of the Verkhovna Rada and interpretations of the Constitutional Court. Article 1". Retrieved from: http://zakon.rada.gov.ua/laws/show/

The Verkhovna Rada of Ukraine (2015) The Law of Ukraine On Voluntary Association of Territorial Communities. Bulletin of the Verkhovna Rada, 13, p. 91.

The Constitution of Ukraine (1996) Retrieved from: http://zakon.rada.gov.ua 